\title{
Building entrepreneurial potential abroad - exploring return migrant experience
}

\author{
Urban Pauli \\ Cracow University of Economics \\ urban.pauli@uek.krakow.pl \\ Renata Osowska \\ Edinburgh Napier University \\ r.osowska@napier.ac.uk
}

\begin{abstract}
Purpose:

This paper examines how entrepreneurial potential is built abroad during periods of EU economic migration and how this affects the entrepreneurial behaviour of individuals after returning to their home country.
\end{abstract}

Design:

A mixed method approach was employed via developing a structured interview discussion guide with open and closed questions centred around the topic of migration, reasons for starting a business and capital (e.g. human, financial, relational) gained abroad. The study covered 54 Polish return entrepreneurs identified through random purposive sampling.

Findings:

The findings suggest an important role of migration on the decision to start a business as almost half of the respondents formulated a business idea during the migration. The capital gains affecting entrepreneurial potential development were mostly observed in terms of financial and human capital with relational capital only applied to a business idea. This may explain individual preferences for setting up a business when returning to the home country. Overall, the findings confirm the important role of economic migration in building the entrepreneurial potential of returnee entrepreneurs.

\section{Originality/value:}

The study explores an alternative to the mainstream assumptions on migration by investigating entrepreneurial individuals, processes and practices that happen during reverse migration. Furthermore, by applying the resource-based view of the firm theory, this research expands the understanding of the inter-relationship between processes of economic migration and entrepreneurial potential development.

Keywords: return migration, entrepreneurial behaviour, entrepreneurial potential, human capital, relational capital, financial capital

Article classification: research paper 


\section{Introduction}

The main aim of this paper is to present the results of exploratory research conducted on a group of Poles who had migrated to Western European countries and returned to Poland where they decided to set up a business. In this paper, a conceptual theoretical model is explored which presents causal relationships between economic migration, the benefits of working abroad and entrepreneurial potential. The abovementioned issues have been widely covered in the literature but in the context of the host country. There is, however, a limited number of articles discussing the entrepreneurial behaviours of returning migrants.

Our study adds to the investigation on how and why entrepreneurship emerges, which has been the most recent postulate in entrepreneurship research. Welter et al. (2017) argue that in order to develop theoretical contributions, scholars need to observe a multiplicity of perspectives on entrepreneurship, which may refer to the drivers of specific entrepreneurial actions or to different factors that shape the general outcome in a specific context. Moreover, according to Nazareno et al. (2018) contexts and conditions in both the host and home countries can impact positively or negatively the ability and willingness to set up own business. Following the call for contextual research, this paper examines: (1) How entrepreneurial potential (in form of resources) is built abroad during economic migration (in particular: What form of capital could be gained while being abroad?; How do migrants accumulate these capitals?); (2) How this affects the entrepreneurial behaviour of individuals after their return to their home country, (3) which of the capitals gained abroad are used in entrepreneurial activity.

The paper is underpinned by academic literature on entrepreneurship and migration; these are a priority for national and international competitiveness agendas. The debate on the implications of migration is a long-standing and ever increasingly important issue. Moreover, recent analysis has confirmed that the majority of migrants eventually return to their home countries (OECD, 2008) and up to 50 per cent return within the first five years of migration. The research presented in this article contributes to the discussion about the role migration can play in economies and societies (Welter et al., 2017), with the focus on returnee entrepreneurs. Furthermore, this research expands the understanding of the inter-relationship between the processes of migration and the development of entrepreneurial potential. In this study, the term 'reverse migration' is applied to describe the process of returning home after living in a foreign country. 
To present a clear understanding of the approach and findings, the remainder of this article is divided into five sections. The first covers theoretical background of the study, referring to migration issues in the EU context (including reverse migration) and to the concept of entrepreneurial potential (based on entrepreneurship and the resourcebased view of the firm). In the second section, the research model and the main goals and propositions are presented. In the third section, the results of the study are analysed, which is followed by a discussion. Finally, a brief conclusion summarises the main points and proposes avenues for further study.

\section{Theoretical background}

\section{Economic migration and reverse migration in the $E U$}

The reasons for migration vary. They are affected by individual circumstances, are largely based on an informed choice and may fluctuate between economic and other reasons. This study focuses only on economic migration, to which economic push-pull theory (King, 2012) can be applied. According to this approach, the decision to seek employment in another country can be based on push factors in the home country (e.g. lack of employment opportunities, societal or civil unrest) or pull factors in the prospective host country (e.g. increased employment opportunities, financial reward or better overall living standards) (Zikic, 2015).

The eastern enlargement of the EU has stimulated the mobility of workers between New and Old Europe from 2004 onwards. This has led to an increase in fears of a huge influx of migration and its negative effect on the receiving countries' labour market combined with shopping attitude benefits (cf. Holland et al., 2011; Kahanec et al., 2010). However, Zaiceva and Zimmermann (2012) suggested that this was mostly a temporal movement initiated by economic conditions (also Marques, 2010) and the commonly referred to 'brain drain or gain' has been replaced by brain circulation. Furthermore, it is suggested that returnees are more likely to migrate again if capital gains become higher. Thus, repeat and circular migration are expected to replace oneway migration in the EU context, which may improve the efficient allocation of migrant resources. Zaiceva and Zimmerman (2012) argue that from the labour market perspective, migrants are very responsive to economic cycles and act as 'buffers' in regulating the labour market in both host and home country. This also leads to the assumption that repeat or circular migration is of benefit to both countries and 
migrants. Thus, highly flexible migration leads to a triple win situation and should be encouraged by stakeholders.

Despite the fact that the process of economic migration (from Eastern Europe countries to the Western countries) is still very common, a reverse trend can be observed. It is noticed that many people who have previously decided to migrate return to their home countries. Different migration theories address the determinants of return, either from perspectives of failure or success (cf. Cassarino, 2004). In this paper, the new economics of labour migration approach (NELM) is applied. This approach sees return as a logical step after economic migrants gather sufficient knowledge and finance to invest in their home country (de Haas et al., 2015). Moreover, in most cases, a return happens when some pre-defined objectives are achieved, such as completing education or accumulating the expected amount of wealth. Thus, a decision to return may be linked to various factors, such as: (1) preference for consumption in the home country, (2) family and other networks at home, (3) differences in relative prices between countries, (4) the possibility of increasing human capital with guarantees of higher returns at home.

The benefits of reverse migration have been observed in home countries through the increase in human capital, productivity and employment. The sending countries also benefit from high level of remittances (especially from temporary migrants with strong connections to the home country and return plans). Reverse migration may also enhance trade and investment, especially in the case of skilled migration; however, all the effects are influenced by migration policies and their success in supporting circular migration (Constant and Zimmermann, 2011).

Evidence of the reverse migration effect can be also traced in the literature about return migrants' entrepreneurship. Recent entrepreneurship research has focused on 'returnees' role as 'super entrepreneurs' with the view that such individuals will affect the rate of business start-ups and job creation (Naude et al., 2015). Research on occupational choice and business activities of return migrants shows that capital accumulated abroad (mostly financial and human) positively impacts entrepreneurship among this group (de Haas, 2006; OECD, 2008; Naude et al., 2015). Nevertheless, Lianos and Pseiridis (2009) argued that the amount of remittance sent back, the acquisition of further qualifications and the duration of migration decreases the likelihood of self-employment. The initial results on post-enlargement countries suggest more likelihood of self-employment in samples (e.g. Martin and Radu, 2012), 
which has been reinforced by most recent literature on entrepreneurship. This study will add to this debate by investigating how economic migration impacts on the development of entrepreneurial potential.

\section{The role of resources in starting a new business}

It could be argued that resource acquisition is essential for successful engagement in an entrepreneurial activity (Qin et al., 2017). Nevertheless, different resources need to be attained to deliver expected outcomes. According to Barney's Resource Based View (RBV) theory (1991), firm resources can be divided into the following three categories: physical capital (plant, equipment, location); human capital (skills, knowledge, experience); organisational capital (structure, internal systems, and relationships among groups within a firm and between a firm and the business environment). Despite the fact that RBV theory was developed mainly with regard to large enterprises, it is applicable to all companies, even those run by the selfemployed. Thus, according to Firkin (2001), RBV attracts the attention of the researchers while analysing entrepreneurial behaviour.

Kellermans et al. (2016) suggest that the entrepreneurial context requires a specific conceptualisation as different dimensions of resources can shape entrepreneurial outcomes. They identified that for entrepreneurial practice, human capital, organisational capital, financial capital, physical capital and relational capital are most relevant. On the basis of these findings, it can be proposed that the capitals that affect entrepreneurial potential at the start-up stage, are human, financial and relational capital whereas organisational and physical capitals are more related to established organisations.

Financial capital includes monetary assets and all other assets that can be easily converted into money (Firkin, 2001; Galbreath, 2005). Depending on the business profile, the stock of financial capital can be used either to invest in tangible assets (machinery, equipment, premises) or in intangible resources (brand, know-how or customer acquisition).

Human capital includes the knowledge, skills, attitudes and abilities (Schultz, 1961; Becker, 1962) which an individual possesses and may use in the process of setting up a new venture. It refers to general knowledge and skills (obtained during education), and to industry-specific knowledge and skills (obtained mostly through occupational experience and training) (Becker, 1962; Firkin, 2001). The industry- 
specific components of human capital that refer to implemented processes, schemes and know-how might become the foundation of the organisational capital (Squicciarini and Le Mouel, 2012) of a future company.

While analysing the role of human capital, the level of educational attainment should also be considered. Jayawarna et al. (2014) found that credentials are negatively associated with entrepreneurial potential as higher qualifications can block risk-taking. Additionally, they found that vocationally oriented courses provide advantages in setting up a business. This suggests that, even though highly skilled individuals are better qualified to become entrepreneurs, in many cases, they have more opportunities to select secure, well-paid employment (Astebro and Bernhardt, 2005).

Relational capital includes all relationships an individual has with other people and with institutions or business partners (Capello and Faggian, 2005). Relational capital is built on the basis of social capital, which is defined in terms of mutual relationships that link different actors in the network (Lin, 2001). However, on the basis of the literature review, Still et al. (2013) found that these two terms are distinct and using them is important for the study of the intangible resources of organisations. Relational capital encompasses not only the value of customer relationships but also the value of relationships with shareholders, governments, partners of strategic alliances and research institutes, as well as the knowledge of market channels and other external networks linked into the organisational value chain (Ordonez de Pablos, 2003).

\section{The development of entrepreneurial potential}

Taking into account that the entrepreneurial potential could be understood as 'an individual's preparedness to engage in typical entrepreneurial activities' (Santos et al., 2013 p.4), we define entrepreneurial potential in this study as the combination of human, financial and relational capital that one can use to establish a new venture in a particular business environment. Moreover, we suggest that these capitals can be compensated by each other. For example, an insufficient stock of financial capital can be balanced with a higher stock of human and/or relational capital. The conceptualisation of this definition is presented in Fig. 1, where the term 'business environment' refers to external factors (such as local infrastructure, demographics, economy, law, demand for particular goods or services etc.) that may impact the possibility to start-up a new enterprise. 


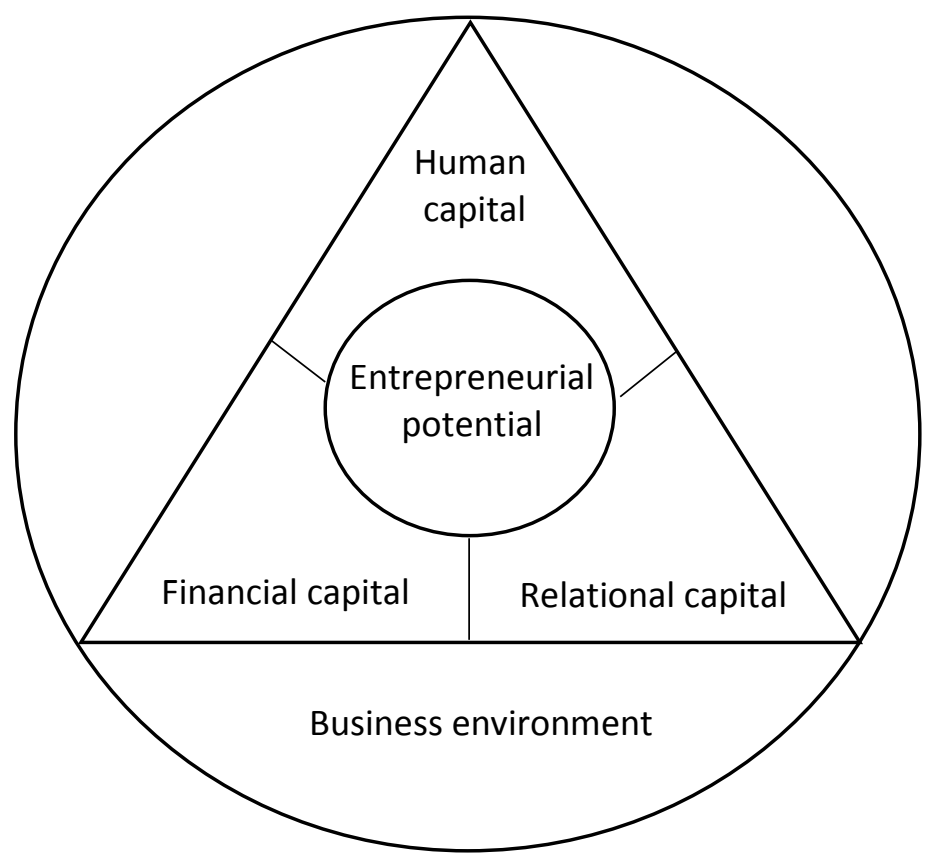

Fig. 1. Entrepreneurial potential components at the start-up stage

\section{Migration and capital enhancements}

Taking into account the reasons behind economic migration, migrants' occupational activities and the process of capital accumulation, it seems that migration can offer an invaluable opportunity for capital gains. This happens especially in situations where migrants believe they have a lot to gain by migrating (cf. Cerdin et al., 2014) or have a higher motivation to perform, especially if they have to support their families (Zikic, 2015). Furthermore, Vershinina et al. (2011) found that differing origins and forms of capital impact the conversion of this capitals into a desirable outcome in a host country The focus on the ways capital can be gained abroad and converted into entrepreneurial activity appears to be relevant to this study. Looking from the perspective of developing entrepreneurial potential, we propose that the enhancement of capitals (financial, human and relational) achieved during migration can be a foothold for setting up a business after returning to the home country. This links to the resource mobilisation argument proposed by Cassarino (2004). Moreover, it is supported by the research of McCormick and Wahba (2001), who found that savings gained in a host country, time spent abroad and experience with a more advanced commercial environment increase probability of starting own business in a home country. 
According to Firkin (2001), any business needs staff, suppliers, materials, and financial assets, which are the inputs the entrepreneur transforms into outputs offered to customers. These components can be acquired in different ways. Financial assets can be obtained from bank loans, grants, business angels, venture capital and other funds. However, in many cases, it is very difficult for people who want to start their own business to apply for these funds in their home country. In such cases, economic migration creates the possibility to achieve higher earnings and save money while working abroad; this may, in turn, be used to fund own business in the home country. It is worth noting that concerning economic migration, in many cases, the cost of setting up and running a business in the home country is lower than in the host country. Thus, considering the economic conditions, migrant's savings can be insufficient to become an entrepreneur in a host country but are enough to start their own business after returning. We, therefore, propose the following:

P1. Working abroad provides returnee migrants with savings required for starting a business in the home country.

Similarly, on the basis of the human capital approach present in theories of migration (Molho, 1986), it can be assumed that working abroad adds to human capital development. Working in another country provides an opportunity to enhance knowledge and skills by attending training courses or through learning by doing. Moreover, working abroad makes it possible to access different forms of employment or even reshape career paths. Observing business processes, procedures and schemes may result in an idea for a business an individual wants to run. Thus, we propose that:

P2 Working abroad increases returnee migrants' human capital, which can be used in starting a business in the home country.

Living and working abroad creates the possibility to develop (and in some situations, forces the creation of) new relationships both at work or in everyday life. This may result in building a network one can use while running own business. However, according to Ryan (2011), the possibility to build networks abroad may depend on economic and social status. In many cases, due to language deficiency or occupational status, migrants have low economic status and their social position can decrease (compared to status in the home country). On the basis of the research conducted on a group of Polish migrants, Ryan (2011) claimed that shared interests, similar careers, educational background and common interests were insufficient to 
build valuable networks in a host country. Despite the fact that such obstacles may appear, migrants establish new relationships in a host country, which in many cases are based on occupational activity. Moreover, connections with organisations supporting entrepreneurs can be developed in a host, as well as in a home country. Additionally, according to Nazareno et al. (2018) individuals migrate not only for education, training or work but also to network and collaborate with their home country counterparts. Thus, migration can provide returnee migrants with relational capital gains. With that in mind, we propose that:

P3. Working abroad enables returnee migrants to create relationships, which can be maintained after returning to the home country and can be valuable for starting a business in the home country.

It can be concluded that migration creates the possibility for financial, relational and human capital enhancements. These capitals are the foundation of entrepreneurial potential and can be used to set up a new business in a particular business context in a home country. However, there are many factors that determine the possibility to enhance different forms of capital. In the case of financial capital, these factors may refer to the type of employment, salary level, costs of living and amount of money sent to family in a home country. According to relational capital, these determinants may refer to those enumerated by Ryan (2011) e.g. occupational status, language fluency or ambitions. In the case of human capital, increases in skills and knowledge can vary due to the tasks performed on the job or the number of training activities provided by the employer.

\section{Theoretical conceptual model}

On the basis of the literature review, the causal model shown in Fig. 2 was developed.

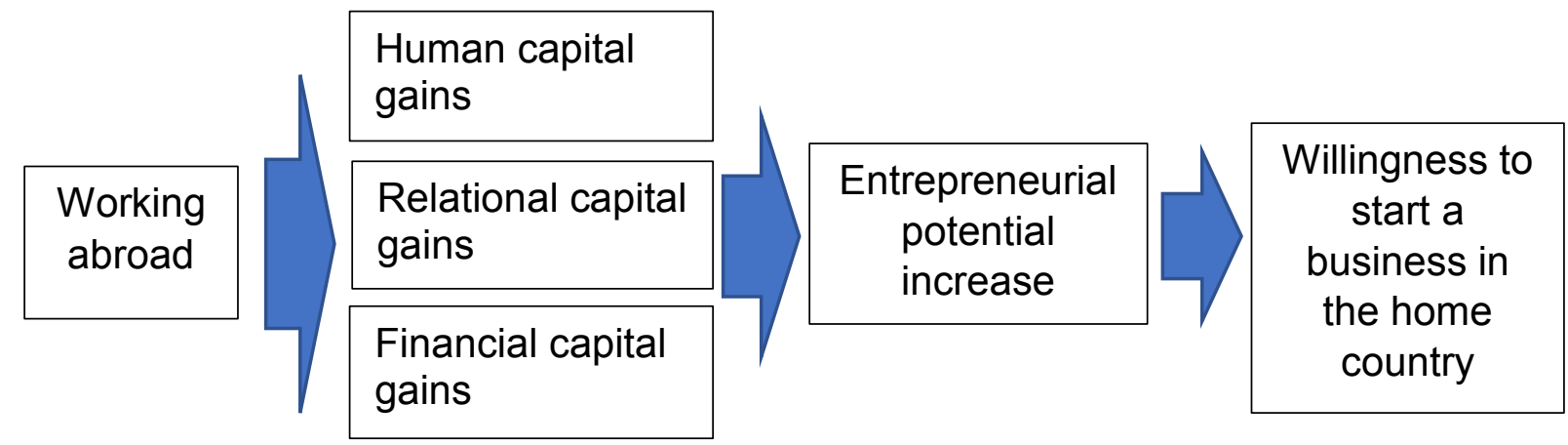

Fig. 2 Theoretical model 
It is proposed that working abroad can provide capital gains by:

- Increasing the value of human capital - migrants can gain new knowledge, skills and change their attitudes, or even develop ideas for business activities.

- Building relationships - for example, with suppliers or customers or by finding business partners.

- Providing funds - in general, the income gained abroad is much higher than in the home country and savings can be used to set up a new business.

Capital enhancement increases an individual's entrepreneurial potential, which can be seen in the willingness to start a business in the home country. This model also assumes that the return migrants might not have planned to start their businesses when migrating and the idea to set up their own venture could have arisen while in a host country or after returning to the home country.

\section{Research method, sample and procedure Methods}

To investigate the development of entrepreneurial potential during EU economic migration, this study focused on exploring the capital gains on a sample of Polish returnee entrepreneurs. This was performed with the use of a convergent parallel mixed method design, combined with a holistic approach (Cameron, 2009). There is no doubt that such an approach fits the reverse migration, which is a complex phenomenon as different processes and interaction happen across international borders over a significant period of time). The rationale for this approach is that a single methodology (whether qualitative or quantitative) is insufficient to answer different types of questions. By synthesising complementary quantitative and qualitative results, a complete understanding of a phenomenon can be developed. The mixed method approach is recommended when qualitative data and its analysis can refine and explain statistical results by exploring participants' views in more depth (Creswell et al., 2003; Tashakkori and Teddlie, 1998). Furthermore, the purpose of the convergent design is 'to obtain different but complementary data on the same topic' (Morse, 1991, p. 122) to best understand the research problem. It is an efficient design in which both types of data are collected during one phase of the research at roughly the same time (Creswell and Plano Clark, 2007). This will be applied in this research 
by using a single study covering two data sets of questions, followed by mixed method analysis and interpretation.

\section{Data collection and analysis}

Similar to Coniglio and Brzozowski (2016), CATI (computer-assisted telephone interviewing) technique was used to collect data. As the main aim of this exploratory study was to verify a capital gains research model, the structured interview consisted of questions clustered into the following sections: (1) occupational status before migration, (2) reasons for migration, (3) occupational status in foreign country, (4) reasons for returning, (4) type of business in the home country, (5) forms of capital gained abroad. Structured interviews are fairly quick to conduct which means that many interviews can take place within a short period of time. Using a telephone-based system also permitted coverage of a wider geographical area. Thus, even if this limits the depth of data, we deem it sufficient for exploratory study.

Following a mixed method approach, multiple-choice, closed- and open-ended questions were used during the interview. This resulted in gathering both quantitative and qualitative data which was compiled and analysed with the use of STATISTICA software. By combining both types of questions in one research instrument, issues of sample inequality were avoided (Creswell and Plano Clark, 2007). Furthermore, a larger sample could be obtained resulting in the findings being more representative and having the ability to be generalised to a larger population, capturing respondents' opinions and experience at this same time. The data was collected and analysed in Polish to avoid any language misunderstanding issues.

\section{Sample description}

The sample consisted of 54 former migrants who had returned to Poland and started their own business. Polish returnees could serve as a good example as according to Martin and Radu (2012), Poland observed the largest proportion of returnees of all accession countries $(7.97 \%)$, which was later confirmed in the study of Zaiceva and Zimmermann (2012). Koehler et al. (2010) also suggested a slowing down of emigration and an increase in return and circular movements in this country. Another study (Smoliner et al., 2012) found that most returnees do not lose connections with their home country during migration, which may help them to re-integrate after returning. The findings of Zaiceva and Zimmermann (2012) also propose that the 
majority of returnees were employed while abroad, supporting the argument of economic migration. In our sample, the majority of migrants returned from the UK to Poland.

The database of The National Bank of Poland was used to select a random, purposive sample. In the sample, only those returnees who had been employed abroad and spent more than a year in a host country were selected for the interview (to exclude seasonal migration). Furthermore, to reduce possible bias in the respondent selection, entrepreneurs from across the whole of Poland were approached. Even though the sample cannot be considered as representative, the data represents the first attempt to map reverse migration entrepreneurship. Sample characteristics are presented in Tables 1-3.

Table 1 Entrepreneur profile
\begin{tabular}{|l|r|r|}
\hline Criteria & $\mathbf{N}$ & $\%$ \\
\hline Gender & & \\
\hline male & 29 & 53.7 \\
\hline female & 25 & 46.3 \\
\hline Age & & \\
\hline under 40 & 19 & 35.2 \\
\hline $40-45$ & 19 & 35.2 \\
\hline 46 and above & 16 & 29.6 \\
\hline Return to home country & & \\
\hline $2000-2008$ & 11 & 20.4 \\
\hline $2009-2011$ & 10 & 18.5 \\
\hline $2012-2014$ & 12 & 22.2 \\
\hline $2015-2017$ & 21 & 38.9 \\
\hline Length of business ownership in the home country (in months) & & \\
\hline up to 18 & 15 & 27.8 \\
\hline $19-36$ & 13 & 24.1 \\
\hline 37-72 & 12 & 22.2 \\
\hline more than 72 & 14 & 25.9 \\
\hline
\end{tabular}

Source: Authors' research

It can be noted in Table 1 that the entrepreneurs where mixed age and gender with various lengths of business ownership in the home country. Furthermore, the majority of returns happened recently, within the last five years or less $(61 \%)$.

Based on the entrepreneurs' background (Table 2), most of the investigated returnees had a low level of education. More than half of the sample $(56 \%)$ had a general secondary education and $22 \%$ of respondents had a secondary vocational level of education. In regard to the occupational status before migration, only 4 out of 54 were running their own business, $20.4 \%$ of respondents were unemployed at the time of 
migration and $18.5 \%$ had just been made redundant. This confirms the economic migration focus of this study.

Table 2 Entrepreneurs' backgrounds

\begin{tabular}{|l|r|r|}
\hline Criteria & N & \multicolumn{1}{|c|}{$\%$} \\
\hline Education level & & \\
\hline primary & 1 & 1.9 \\
\hline secondary vocational & 12 & 22.2 \\
\hline secondary general & 30 & 55.6 \\
\hline higher (BA or MA) & 11 & 20.4 \\
\hline Occupational status before migration & & \\
\hline I was unemployed & 11 & 20.4 \\
\hline I have just graduated & 0 & 0.0 \\
\hline I was running my own business & 4 & 7.4 \\
\hline I was studying and working & 1 & 1.9 \\
\hline I was employed in a micro firm (up to 10 employees) & 9 & 16.7 \\
\hline I was employed in a small firm (10-49 employees) & 13 & 24.1 \\
\hline I was employed in a medium firm (50-250 employees) & 2 & 3.7 \\
\hline I was employed in a large firm (more than 250 employees) & 4 & 7.4 \\
\hline I have just resigned or been made redundant & 10 & 18.5 \\
\hline
\end{tabular}

Source: Authors' research

Taking into account the type of business entrepreneurs run in the home country (Table 3 ), it can be observed that almost all of them operated in services and in industries that are not knowledge-intensive. In particular, $27.8 \%$ operated in construction/interior work, $11.1 \%$ in retail, $18.6 \%$ in services for the general public, $7.4 \%$ in catering/gastronomy and $7.4 \%$ in transport services. Moreover, in $52 \%$ of cases, these businesses operated in local markets and $26 \%$ in regional.

Table 3 Business profile

\begin{tabular}{|l|r|r|}
\hline Criteria & $\mathbf{N}$ & \multicolumn{1}{|c|}{$\%$} \\
\hline Type of business opened after the return & & \\
\hline construction/interior work & 15 & 27.8 \\
\hline retail & 6 & 11.1 \\
\hline elderly support & 5 & 9.3 \\
\hline hairdresser & 5 & 9.3 \\
\hline catering/gastronomy & 4 & 7.4 \\
\hline transport services & 4 & 7.4 \\
\hline architecture/interior design & 3 & 5.6 \\
\hline cleaning & 3 & 5.6 \\
\hline car mechanics & 2 & 3.7 \\
\hline training & 2 & 3.7 \\
\hline IT & 1 & 1.9 \\
\hline car retail & 1 & 1.9 \\
\hline real estate & 1 & 1.9 \\
\hline production & 1 & 1.9 \\
\hline joinery & 1 & 1.9 \\
\hline
\end{tabular}




\begin{tabular}{|l|r|r|}
\hline Market the business operates in & & \\
\hline local & 28 & 51.9 \\
\hline regional & 14 & 25.9 \\
\hline domestic & 8 & 14.8 \\
\hline international & 4 & 13.0 \\
\hline
\end{tabular}

Source: Authors' research

\section{Results}

\section{Human capital gains}

Most of the respondents $(82.2 \%)$ claimed they had acquired new knowledge abroad (see Table 4); this corresponded most frequently to their initial occupation, but in one in three cases, it helped migrants to deliver new tasks related to a new occupation. This new knowledge was mostly acquired by fulfilling complex and varied tasks and by following instructions provided by more experienced colleagues or acquaintances. Thus, it can be assumed that in most cases, respondents were learning by doing, and this process was rather informal. Interestingly, in almost $40 \%$ of cases, new knowledge acquisition resulted from self-initiated actions (self-financed training or courses and self-study).

Table 4. Knowledge and skills acquisition

\begin{tabular}{|l|r|r|}
\hline Have you acquired new knowledge while being abroad? & $\mathbf{N}$ & \multicolumn{1}{c|}{$\%$} \\
\hline $\begin{array}{l}\text { Yes, I gained new knowledge that directly corresponds to my initial } \\
\text { occupation* }\end{array}$ & 21 & 38.9 \\
\hline Yes, I gained new knowledge which helped me deliver new tasks & 18 & 33.3 \\
\hline $\begin{array}{l}\text { Yes, I gained new knowledge that did not correspond to the occupation in } \\
\text { which I was initially trained but helped me to find a job in a different field }\end{array}$ & 5 & 9.3 \\
\hline No, I did not gain any new knowledge & 15 & 27.8 \\
\hline How have you acquired new knowledge? & $\mathbf{N}$ & \multicolumn{1}{c|}{$\%$} \\
\hline By fulfilling complex and varied tasks & 18 & 33.3 \\
\hline By instructions provided by more experienced colleagues/acquaintances & 18 & 33.3 \\
\hline By attending training provided by the organisation I worked for & 6 & 11.1 \\
\hline By attending training or courses which I financed myself & 7 & 13.0 \\
\hline Through self-study & $\mathbf{N}$ & 25.9 \\
\hline Have you developed skills while being abroad & 8 & 14.8 \\
\hline $\begin{array}{l}\text { Yes, I have developed skills that directly correspond to my initial } \\
\text { occupation }\end{array}$ & 29 & 53.7 \\
\hline Yes, I have developed skills which have helped me deliver new tasks & 5 & 9.3 \\
\hline $\begin{array}{l}\text { Yes, I developed skills that did not correspond to the occupation in which I } \\
\text { was initially trained but helped me to find a job in a different field }\end{array}$ & 12 & 22.2 \\
\hline No, I have not acquired new skills while being abroad & $\mathbf{N}$ & $\%$ \\
\hline How have you acquired new skills & 18 & 33.3 \\
\hline By fulfilling complex and various tasks & 12 & 22.2 \\
\hline $\begin{array}{l}\text { By instructions provided by more experienced colleagues or } \\
\text { acquaintances }\end{array}$ & 6 & 11.1 \\
\hline By attending training provided by the organisation I worked for & \\
\hline
\end{tabular}


By attending training or courses which I financed on my own

By observing more experienced co-workers

In another way

Source: Authors' research

* Note: in this paper 'initial occupation' refers to the occupation for which the individual was initially trained

More respondents (87.8\%) reported the development of new skills than reported the acquisition of knowledge. Moreover, in $53.7 \%$ of cases, these skills helped them to fulfil new tasks within their initial occupation. Similar to knowledge acquisition, skills development was achieved through informal techniques. One out of every three interviewees claimed that fulfilling complex and varied tasks was the most beneficial activity for skill development. Of those interviewed, $22.2 \%$ followed instructions provided by more experienced colleagues or acquaintances.

Over half $(51.9 \%)$ of all returnee entrepreneurs found their acquired knowledge to be either a primary factor $(13.0 \%)$ or very important $(38.9 \%)$ in running their businesses in Poland. None claimed not to use it at all (see Table 5). However, acquired skills seemed to be less important than knowledge in running own business. Only $9.3 \%$ of entrepreneurs found these skills to be the primary factor, and $38.9 \%$ believed them to be very important. Moreover, merely $6 \%$ of entrepreneurs did not use acquired skills in their business activity.

Table 5. The usage of new knowledge and skills in running businesses

\begin{tabular}{|c|c|c|}
\hline $\begin{array}{l}\text { To what extent do you use your acquired knowledge in running your } \\
\text { business? }\end{array}$ & $\mathbf{N}$ & $\%$ \\
\hline It is the primary factor & 7 & 13.0 \\
\hline It is very important & 21 & 38.9 \\
\hline It is quite important, I use most of it & 10 & 18.5 \\
\hline I occasionally use some components of it & 0 & 0.0 \\
\hline I tend not to use it & 1 & 1.9 \\
\hline I definitely do not use it & 0 & 0 \\
\hline To what extent do you use acquired skills in running your business? & $\mathbf{N}$ & $\%$ \\
\hline They are the primary factor & 5 & 9.3 \\
\hline They are very important & 21 & 38.9 \\
\hline They are quite important, I use most of them & 13 & 24.1 \\
\hline I rather do not use them & 1 & 1.9 \\
\hline I do not use them at all & 2 & 3.7 \\
\hline
\end{tabular}

Source: Authors' research

Entrepreneurs were also asked if any specific skills/knowledge were required when starting a new venture. $38.9 \%$ respondents confirmed that they made use of either 
industry- or firm-specific skills/knowledge. In this group of entrepreneurs, two out of three claimed they had acquired them while being abroad.

\section{Relational capital gains}

Most of the respondents $(72.2 \%)$ did not set up new relationships while abroad which helped them run their current business (see Table 6). Moreover, of those who developed relationships, $27.8 \%$ claimed that they had done so with Poles, either living in Poland (13.0\%) or living in a host country (14.8\%). Only $9.3 \%$ established businessrelated relationships with people were from other nationalities.

Table 6. The characteristics of relationships set up during migration

\begin{tabular}{|l|c|c|}
\hline $\begin{array}{l}\text { Have you set up new relationships while abroad which are used in the } \\
\text { running your business? }\end{array}$ & $\mathbf{N}$ & $\mathbf{\%}$ \\
\hline No, I have not set up relationships abroad that I use in running my business & 39 & 72.2 \\
\hline Yes, but with Poles living in Poland while I was abroad & 7 & 13.0 \\
\hline Yes, with other Poles living in a host country & 8 & 14.8 \\
\hline Yes, with people of other nationalities & 5 & 9.3 \\
\hline Which statement characterises the form of this cooperation? & $\mathbf{N}$ & $\%$ \\
\hline They are suppliers & 4 & 7.4 \\
\hline They are customers & 5 & 9.3 \\
\hline They are co-owners & 1 & 1,9 \\
\hline $\begin{array}{l}\text { They are business partners (e.g. they offer my products or services, we jointly } \\
\text { acquire customers, we are cooperating in completing orders) }\end{array}$ & 10 & 18.5 \\
\hline
\end{tabular}

Source: Authors' research

The relationships set up while abroad mainly resulted in creating business partnerships in the form of cooperation in customer acquisition or completing orders. In some cases, respondents also acted as suppliers or customers. Only one entrepreneur confirmed that the relationship set up during migration resulted in coownership of a new venture. Furthermore, none of those interviewed confirmed membership of any professional or business organisations/institutions in a host country. Additionally, most of the relational capital gains resulted from self-initiated and informal activities.

\section{Financial capital gains}

Almost all respondents (96.3\%) claimed that they had saved money while abroad (see Table 7). More than two-thirds declared they saved the amount that they had initially planned $(48.1 \%)$ or more than they had expected $(20.4 \%)$. These results confirm that 
working in a host country provides an opportunity to earn a much higher salary than in the home country and supports the economic migration argument.

Table 7. Savings and their impact on setting up new businesses

\begin{tabular}{|l|c|r|}
\hline Have you saved any money while working abroad? & $\mathbf{N}$ & $\boldsymbol{\%}$ \\
\hline No, and I had to spend my savings from my home country & 0 & 0.0 \\
\hline No, I haven't saved any money & 2 & 3.7 \\
\hline Yes, I have saved some money but less than I had initially planned & 15 & 27.8 \\
\hline Yes, I have saved as much as I had initially planned & 26 & 48.1 \\
\hline Yes, I have saved more than I had initially planned & 11 & 20.4 \\
\hline Have you spent your savings on setting up your business? & $\mathbf{N}$ & $\%$ \\
\hline Yes, and it was a sufficient amount of money & 32 & 59.3 \\
\hline Yes, but it was not enough and I had to find additional sources of funding & 15 & 27.8 \\
\hline No, I haven't spent my savings on setting up a new business & 5 & 9.3 \\
\hline I have not saved money & 2 & 3.7 \\
\hline
\end{tabular}

Source: Authors' research

In most cases (59.3\%), the amount of money saved was sufficient to set up a new business. More than one in four respondents spent all their savings and additionally had to apply for funds from other sources. Only in $9.3 \%$ of cases were savings not spent on the entrepreneurial activity.

\section{The role of migration in starting own business - the overall perception}

In the sample, $98 \%$ of respondents confirmed they had planned to return to the home country; this supports the new economics of labour migration assumption which sees return as a logical step after migrants gather sufficient knowledge and finance to invest in their home country (de Haas et al., 2015). When asked to point out the importance of various factors that supported the decision to return, $61 \%$ of entrepreneurs claimed that saving initially planned amount of money was a primary or very important factor; while $39 \%$ chose gaining initially planned knowledge, skills and professional experience. However, the emerging possibility to set up own business in a home country was most important ( $63 \%$ found it to be primarily or very important). Furthermore, many of the respondents mentioned a combined motivation of both elements. For example, one respondent commented:

'Over two years I saved a sufficient amount of money and I knew I could afford to open my own business in the country (Poland), also I didn't want to work so hard anymore.' Most of the entrepreneurs (83\%) also added personal reasons that affected their return: 
'I had earned as much as I planned, but also I missed my family and country and I have reached a certain age.'

Another mentioned:

'I missed my loved ones, I also felt discriminated against.'

In $27.8 \%$ of cases (see Table 8 ), the idea to start a new business had arisen before leaving the home country. In such cases, it can be assumed that migration was intended to provide the means for starting a new venture. These entrepreneurs had identified specific goals and they returned home after achieving them. However, $46.3 \%$ of respondents came up with the idea of running their own enterprise while abroad, even though $18.5 \%$ had to modify it after returning.

Table 8. The point at which decision on starting a business was made

\begin{tabular}{|l|l|l|}
\hline When did the idea of starting a business come to you? & $\mathbf{N}$ & $\mathbf{\%}$ \\
\hline Before migration & 15 & $27.8 \%$ \\
\hline While abroad & 15 & $27.8 \%$ \\
\hline While abroad, but I had to modify it on returning & 10 & $18.5 \%$ \\
\hline After returning & 14 & $25.9 \%$ \\
\hline
\end{tabular}

Source: Authors' research

Two out of every three respondents stated they were the sole originator of the new business idea (see Table 9). Concerning the migration effect, $37 \%$ of cases were supported by friends who lived abroad and in $7.4 \%$, by institutions or organisations supporting new ventures in the host country. Thus, it can be concluded that in at least $44.4 \%$ of cases, migration had a high impact on idea development.

Table 9. People involved in creating a business idea

\begin{tabular}{|l|c|c|}
\hline $\begin{array}{l}\text { Who was involved in the process of creating a new business } \\
\text { idea? }\end{array}$ & $\mathbf{N}^{*}$ & $\%$ \\
\hline It was solely my idea & 36 & 66.7 \\
\hline My friends abroad supported me in designing the new business & 20 & 37.0 \\
\hline $\begin{array}{l}\text { My friends from my home country supported me in designing new } \\
\text { business }\end{array}$ & 17 & 31.5 \\
\hline $\begin{array}{l}\text { I received general support from a host-country } \\
\text { organisation/institution in setting up a business which I applied on } \\
\text { return to my home country }\end{array}$ & 4 & 7.4 \\
\hline $\begin{array}{l}\text { I was assisted by organisations/institutions supporting new } \\
\text { ventures in my home country on returning }\end{array}$ & 3 & 5.6 \\
\hline
\end{tabular}

Source: Authors' research

* Respondents could choose more than one answer 
Respondents were also asked in an open question to enumerate the benefits of migration. The coding applied identified 'improving financial condition' (37\%), and 'saving money for own business' (31.5\%) as most commonly mentioned. A quarter claimed they had an 'interesting life experience which allowed self-development' (referring mostly to self-awareness, self-confidence, stress tolerance). Some profits connected with human capital development were also highlighted. These included 'work experience' (25.9\%), acquisition of 'knowledge' (16.7\%), 'skills' (11.1\%) and improving 'foreign language fluency' (14.8\%).

The positive attitude towards migration was apparent in statements such as:

'Those who returned, despite the fact that they are frustrated, somehow have more hope and do not complain so much because if they feel very bad, they can leave the country without any fear. The 'work shy' always complain and do not leave, which is annoying. It is always easier to blame the government and officials, but abroad we learn to take matters into our own hands. I personally recommend that.'

\section{Discussion}

The data gathered confirms that working abroad creates many possibilities to gain capital that may have a positive impact on increasing entrepreneurial potential. This is in line with previous research (de Haas, 2006; OECD, 2008; Martin and Radu, 2012; Naude et al., 2015) and supports findings that capital accumulated abroad positively impacts the likelihood of becoming self-employed. However, according to the results, not all capitals were enhanced at the same level neither were they used to the same extent while starting own business.

The most important capital acquired abroad was financial, which adds to the economic migration argument (Zaiceva and Zimmermann, 2012). Almost all respondents $(96.3 \%)$ claimed they had saved money while working in a host country. Moreover, $87.1 \%$ declared they have spent their savings on a new venture and it was a primary factor in their start-up choice. This supports the first proposition that 'working abroad provides returnee migrants with savings required for starting their business in a home country'.

A positive impact of migration can be also identified when considering human capital. Of those interviewed, $82.2 \%$ declared the acquisition of new knowledge and $87.8 \%$ confirmed the development of new skills. Moreover, nearly half of respondents $(51.9 \%$ in the case of knowledge, and $48.2 \%$ in the case of skills) claim that acquired $\mathrm{HC}$ 
components are the primary factor or are very important in running their ventures. Only a small minority of returnee entrepreneurs claimed not to use new or developed knowledge/skills in their business activity in a home country. Thus, it can be concluded that the findings support the second proposition that 'working abroad increases returnee migrants' human capital which is used in starting a business in a home country'. This argument is also supported by $46.3 \%$ of respondents coming up with an idea to run own business while staying abroad. These findings also refer to the 'brain circulation' argument (Zaiceva and Zimmerman, 2012; Marques, 2010) suggesting an important role of migrants in building an entrepreneurial society in the transnational context. Undoubtedly, returnee migrants made use of their human capital developed in the home country while working abroad. However, the components of human capital such as knowledge and skills were expanded in a host country and (according to the data gathered) are now applied in running a business. Such findings refer directly to the 'triple win situation' as migrants, host and home country benefited from migration. However, based on the findings, the relational capital acquired during migration was much less used in the business context. Only $27.8 \%$ of respondents confirmed building a business network abroad. Moreover, most of them set up new relationships with other Poles, either in Poland or in a host country. Relationships with people of other nationalities were set up by only $9.3 \%$. Surprisingly, such a situation does not stem from potential difficulties with cross-cultural awareness as only $15 \%$ of respondents found cultural differences as a primary or very important factor supporting a decision to return. Furthermore, none of the interviewees confirmed membership of any professional, or business organisation/institution in a host country. The reasons behind not building relational capital may refer to Ryan's (2011) findings, which state that the possibility of building networks depends on economic and social status as well as language fluency, occupational status and unfulfilled personal ambitions. On the basis of the sample's characteristics, the return migrants had a rather unsatisfactory occupational situation which triggered their economic migration. Nearly $40 \%$ were unemployed, $7 \%$ were studying and working part-time and $18.7 \%$ were employed in a micro-firm. Moreover, most of them claimed that one of the most important benefits of working abroad was learning a foreign language. This can lead to the assumption that at the time of migrating, their fluency in the foreign language was rather unsatisfactory. All these arguments support Ryan's (2011) findings that even if Poles established relationships, they were rather low and did not provide them with an opportunity to 
share different types of resources (especially after returning). Thus, it can be posited that the results do not support the third proposition that 'Working abroad enables returnee migrants to create relationships required for starting a business in a home country'. This, however, might suggest a shortfall in one capital can be compensated for with strengths in other capitals.

On the basis of the migrants' educational level, it can be also concluded that our findings are in line with those reported by Jayawarna et al. (2014) and Coniglio and Brzozowski (2016). Most of the investigated return migrant entrepreneurs (56\%) had a general secondary education and $22 \%$ of respondents had a secondary vocational level of education, which means they were prepared for fulfilling specific but simple tasks. Thus, it can be concluded that they had fewer possibilities to find secure and well-paid jobs and used their capitals to start a business instead.

\section{Implications}

Despite the fact that the results confirming human and financial capital gains are in accordance with the model, the relational capital enhancement was less visible. Polish entrepreneurs seemed not to develop business relationships while abroad; however, some relationships played an important role in the business idea development stage. Thus, taking into account respondents' educational and business profiles, this may imply that the types of businesses they opened may have required a low level of relational capital. The sample consisted of mostly low-skilled former migrants who started low knowledge-intensive businesses. This also implies the importance of financial capital (which makes it possible to start a new business, for example by providing funds for initial equipment and premises) in this context.

It can also be assumed that for the majority of returnee entrepreneurs, the decision to migrate was dictated by a difficult employment situation (push); it impacted their main motivation for gaining the capital abroad (mostly financial but also human) and to return after achieving expected outcomes (de Haas et al., 2015). In this sense, achieving an expected amount of wealth combined with family and other networks at home supports the NELM argument and compensation of capitals. The findings also confirm that in this case, the likelihood of starting a business could be negatively correlated with the acquisition of further qualifications and the duration of migration (Lianos and Pseiridis, 2009). This can also be explained by the informal and individual ways in which human and relational capital was acquired, developed and transferred 
into entrepreneurial potential which impacts the resource mobilisation patterns (cf. Cassarino, 2004). Thus, our sample ( which largely consisted of low-skilled migrants) was focused on accumulating mostly financial and human capital while abroad (de Haas, 2006; OECD, 2008, Naude et al., 2015), and planning to return.

Since the research focus was on temporal economic migration, it could be argued that low-skilled migration, focussed on doing low-skilled work, is more repeatable. This may also suggest that in this case, capital development requires a longer process and multiple movements to reach the expected outcomes. Considering the context of migration in this study, there might also be other reasons for going abroad (especially fast access to money and family responsibilities mentioned by Zikic (2015) that are in line with NELM theory). From our findings, the temporality of migration induced by social ties can also explain the lack of relational capital development which may require a longer period to develop abroad in comparison to other forms of capital. It appears that financial capital might be the fastest form of capital to gain during temporary migration; this is supported by our findings.

Only $27.8 \%$ of returnee entrepreneurs migrated in order to expand on business resources while the remaining majority did develop their entrepreneurial potential while staying abroad. This adds an important dimension to the model as different stages of the development of entrepreneurial potential may impact expected capital gains. Apart from finance, which is the major reason for economic migration, entrepreneurial potential during temporary migration is mostly build through knowledge transfer. This could be related to human capital development, especially in the context of economic migration. Finally, with regard to different forms of capital as a resource enabling business start-up, it seems that industry-specific human capital did, in fact, converge into the organisational capital of returnees' businesses.

Based on the above points, the implications for policy and practice are as follows. Concerning the profile of returnee entrepreneurs and temporality of economic migration, more targeted support could be provided to establish entrepreneurship in the home country in order to transform entrepreneurial potential into more beneficial entrepreneurial behaviour. Furthermore, training could be provided to effectively use the capitals to expand on the businesses profile and capital gains. If, however, the host country would like to increase the level of entrepreneurship in the transnational context (which will enhance trade and investment) they should provide better access and support for building networks while abroad, acknowledging the temporality of 
economic migration and the context of repeat and circular migration. This could also promote a triple win situation in the longer perspective.

\section{Conclusion and recommendations for further research}

This study aimed to identify how entrepreneurial potential (in form of resources) is built abroad during migration and how this affects the entrepreneurial behaviour of individuals after their return to their home country. This was investigated on a sample of 54 return migrant entrepreneurs who set up their business in Poland. On the basis of the exploratory study, it can be confirmed that economic migration creates opportunities to gain financial capital and to further develop human capital. Moreover, these two types of resources are treated by returning migrant entrepreneurs as primary or very important factors impacting the decision to set up a new venture. Furthermore, on the basis of the data gathered, it can be concluded that returning migrant entrepreneurs merely build business relationships while abroad and they do not create business networks with any institution aimed at supporting entrepreneurs in the host country. This might be linked to the temporality of economic migration and the time required to develop different forms of capital (resource allocation).

By investigating the reverse migration context, this research offers an expansion on the understanding of the interrelationship between migration and entrepreneurial behaviour. Moreover, this study expands the understanding of the interdependence between migration and entrepreneurial behaviour by observing the reverse migration process. It was possible to capture how migration experiences impact upon business start-up and how migrant experiences facilitate alternative ways of enterprise development in the home country through developing entrepreneurial potential abroad.

However, our study is not short of limitations, one of the most significant being the limited sample and an exploratory focus. Since no other study has performed similar research, this was the first attempt to investigate the impact of economic migration on capital gains and entrepreneurial potential development. Limitations referring to the method chosen and possible self-selection bias suggest potential avenues for further studies. For example, acknowledging the variety of return migrant experience with regard to both employability and reasons behind migration can be further linked to different forms of capital gains and the time required for their development. These 
variables may play a moderating role in both capital gain processes and setting up a new business. To investigate this further, we suggest expanding on the concept of the development of entrepreneurial potential in relation to capital gains and the time required to acquire them.

Four main recommendations for further research can be highlighted. Firstly, the sampling process should make it possible to include entrepreneurs that represent high- and low-skilled migrants to assess the effect of economic migration from different theoretical perspectives and with regard to various types of businesses. Secondly, a control sample consisting of returnee migrants who are not entrepreneurs and entrepreneurs who are not migrants should be added to assess the research validity. Thirdly, this research should be conducted on a larger sample of returned migrant entrepreneurs, recognising a variety of host countries' experiences and including migrants of other nationalities rather than restricting the sample to Poles. Finally, the whole investigation would benefit from considering entrepreneurs' individual characteristics.

\section{References:}

Astebro, T. and Bernhardt, I. (2005), "The winner's curse of human capital", Small Business Economics, Vol. 24 No. 1, pp. 63-78.

Barney, J.B. (1991), "Firm resources and sustained competitive advantage", Journal of management, Vol. 17 No. 1, pp. 99-120.

Becker, G. S. (1962), "Investments in human capital: a theoretical analysis", The Journal of Political Economy, Vol. 70 No. 2, pp. 9-49.

Cameron, R. (2009), "A sequential mixed model research design: design, analytical and display issues", International Journal of Multiple Research Approaches, Vol. 3 No. 2, pp.140-152.

Capello, R. and Faggian, A. (2005), "Collective learning and Relational Capital in Local Innovation Process, Regional Studies, Vol. 39 No. 1, pp. 75-87.

Cassarino, J. P. (2004). "Theorising Return Migration: A Conceptual Approach to Returnees Revisited", International Journal on Multicultural Societies, Vol. 6 No. 2, pp. 253-279.

Cerdin, J.L., Diné, M.A. and Brewster, C. (2014), "Qualified immigrants' success: Exploring the motivation to migrate and to integrate", Journal of International Business Studies, Vol. 45 No.2, pp.151-168.

Constant, A.F. and Zimmermann, K.F. (2011), "Circular and repeat migration: counts of exits and years away from the host country", Population Research and Policy Review, Vol. 30 No. 4, pp. 495-515.

Creswell, J. and Plano Clark, V. (2007), Designing and Conducting Mixed Methods Research, Sage, Thousand Oaks. CA.

Creswell, J.W., Plano Clark, V.L., Gutmann, M.L., and Hanson, W.E. (2003), "Advance mixed methods research designs", in Tashakkori A. \& Teddlie C. 
(Eds.), Handbook of mixed methods in social and behavioral research, Sage, Thousand Oaks CA, pp. 219-240.

Coniglio, N.D. and Brzozowski, J. (2016), "Migration and development at home: Bitter or sweet return? Evidence from Poland", European Urban and Regional Studies Vol. 25 No. 1, pp. 85-105.

de Haas, H. (2006), "Engaging diasporas. How governments and development agencies can support diaspora involvement in the development of their origin countries", available at:

http://www.heindehaas.com/Publications/de $\% 20$ Haas $\% 202006 \% 20$ -

\%20Engaging\%20Diasporas.pdf (accessed 27 February 2018).

de Haas, H., Fokkema, T. and Fihri, M.F. (2015), "Return migration as failure or success?" Journal of International Migration and Integration, Vol.16 No.2, pp.415429.

Firkin P. (2001), "Entrepreneurial Capital: A resource-Based conceptualisation of the entrepreneurial process", Working Paper no 7, Albany and Palmerston North Labour Market dynamics Research programme, Massey University, Auckland, New Zealand, ISSN: 1175-6683, available at:

http://newsettlers.massey.ac.nz/publications Imd/working\%20paper\%20no.\%207. pdf (accessed 27 February 2018).

Galbreath, J. (2005), "Which resources matter the most to firm success? An exploratory study of resource-based theory", Technovation, Vol.25 No.9, pp. 979987.

Holland, D., T. Fic, A. Rincon-Aznar, L. Stokes, and Paluchowski P. (2011), "Labour mobility within the EU - The impact of enlargement and the functioning of the transitional arrangements. Final Report", Study for the DG Employment, Social Affairs and Inclusion, European Commission. National Institute of Economic and Social Research, London, available at:

http://csdle.lex.unict.it/docs/labourweb/Labour-mobility-within-the-EU-The-impactof-enlargement-and-the-functioning-of-the-transitional-arra/1903.aspx (accessed 27 February 2018).

Jayawarna, D., Jones, O. and Macpherson, A. (2014), "Entrepreneurial potential: The role of human and cultural capitals", International Small Business Journal, Vol. 32 No. 8, pp. 918-943

Kahanec, M., Zaiceva, A. and Zimmermann, K.F. (2010), "Lessons from Migration after EU Enlargement”, in: M. Kahanec and Zimmermann K. F. (eds.), EU Labor Markets after Post Enlargement Migration, Springer, Berlin, pp. 3-45.

Kellermanns, F., Walter, J., Crook, T.R., Kemmerer, B. and Narayanan, V. (2016), "The resource-based view in entrepreneurship: A content-analytical comparison of researchers' and entrepreneurs' views", Journal of Small Business

Management, Vol.54 No.1, pp. 26-48.

King, R. (2012), "Theories and typologies of migration: An overview and primer". Willy Brandt Series of Working Papers in International Migration and Ethnic Relations, 3/12, available at: http://www.mah.se/upload/Forskningscentrum/MIM/WB/WB\%203.12.pdf (accessed 27 February 2018).

Koehler, J., Laczko, F., Aghazarm, C. and Schad, J. (2010), "Migration and the Economic Crisis in the European Union: Implications for Policy", IOM Thematic Study, IOM, Brussels, available at: http://publications.iom.int/system/files/pdf/migration and the economic crisis.pdf, (accessed 27 February 2018). 
Lianos, T. and Pseiridis, A. (2009), "On the occupational choices of return migrants", Entrepreneurship and Regional Development, Vol.21 No.2, pp.155-181.

Lin, N. (2001), Social Capital: A Theory of Social Structure and Action, Cambridge University Press, New York, NY.

Marques, H. (2010), "Migration creation and diversion in the European Union: Is Central and Eastern Europe a 'natural' member of the single market for labour?", Journal of Common Market Studies, Vol.48 No.2, pp. 265-291.

Martin, R. and Radu, D. (2012), "Return migration: the experience of Eastern Europe", International Migration, Vol.50 No.6, pp.109-128.

McCormic, B. and Wahba, J. (2001), "Overseas work experience, savings and entrepreneurship amongst return migrants to LCDs", Scottish Journal of Political Economy, Vol. 48 No. 2, pp.164-178.

Molho, I. (1986), "Theories of migration", British Journal of Political Economy, Vol. 33, No. 4, pp. 396-419.

Morse, J. M. (1991), "Approaches to qualitative-quantitative methodological triangulation", Nursing Research, Vol.40 No.2, pp. 120-123.

Naudé, W., Siegel, M. and Marchand, K. (2015), "Migration, entrepreneurship and development: A critical review", UNU-MERIT Working Papers ISSN 1871-9872, available at: http://ftp.iza.org/dp9284.pdf (accessed 27 February 2018).

Nazareno, J., Zhou, M. and You, T. (2018), "Global dynamics of immigrant entrepreneurship: Changing trends, ethnonational variations, and reconceptualizations", International Journal of Entrepreneurial Behavior \& Research, https://doi.org/10.1108/IJEBR-03-2018-0141 (accessed 12 October 2018).

OECD, (2008), International migration outlook 2008, OECD, Paris.

Ordonez de Pablos, P. (2003), "Measuring and reporting on relational and social capital: empirical evidences", Conference OLKC4, https://warwick.ac.uk/fac/soc/wbs/conf/olkc/archive/oklc4/papers/oklc2003 ordone z.pdf (accessed 21 June 2018)

Qin, F., Wright, M. and Gao, J. (2017), "Are 'sea turtles' slower? Returnee entrepreneurs, venture resources and speed of entrepreneurial entry", Journal of Business Venturing, Vol.32 No.6, pp.694-706.

Ryan, L. (2011), "Migrant's social networks and weak ties: accessing resources and constructing relationships post migration", The Sociological Review, Vol. 54 No. 4, pp. 707-724

Smoliner, S., Förschner, M., Hochgerner J., and Nova J. (2012), "Comparative Report on Re-Migration Trends in Central Europe”, Re-Turn Consortium, Leibniz Institute for Regional Geography, Leipzig, available at:

http://www.central2013.eu/fileadmin/user upload/Downloads/outputlib/Re-

Turn Comparative Report.pdf (accessed 27 February 2018).

Santos, S.C., Caetano, A. and Curral, L. (2013), "Psychosocial aspects of entrepreneurial potential”, Journal of Small Business \& Entrepreneurship, Vol.26 No.6, pp. 661-685.

Schultz, T. (1961), "Investment in Human Capital", The American Economic Review, Vol.51 No.1, pp. 1-17.

Squicciarini, M. and Le Mouel, M. (2012), "Defining and Measuring Investment in Organisational Capital: Using US Microdata to Develop a Task-based Approach", OECD Science, Technology and Industry Working Papers, 2012/05. OECD Publishing, available at: http://dx.doi.org/10.1787/5k92n2t3045b-en (accessed 27 February 2018). 
Still, K., Huhtamäki, J. and Russell, M.G. (2013), "Relational Capital and Social Capital: One or two Fields of Research?", in Green, A. (ed.), Proceedings of the 10th International Conference on Intellectual Capital, Knowledge Management and Organisational Learning, Vol. 2, ICICKM 2013, Washington, DC, USA, October 24-25, 2013, Academic Conferences and Publishing International Limited, Reading, UK, pp. 420-428.

Tashakkori, A. and Teddlie, C. (1998), Mixed methodology: Combining qualitative and quantitative approaches. Sage, Thousand Oaks CA.

Vershinina, N., Barrett, R. and Meyer, M. (2011), "Forms of capital, intra-ethnic variation and Polish entrepreneurs in Leicester", Work, employment and society, Vol. 25 No.1, pp.101-117.

Welter, F., Baker, T., Audretsch, D.B. and Gartner, W.B. (2017), "Everyday

Entrepreneurship - A Call for Entrepreneurship Research to Embrace Entrepreneurial Diversity", Entrepreneurship Theory and Practice, Vol.41 No.3, pp. 311-321.

Zaiceva, A. and Zimmermann, K.F. (2012), "Returning Home at Times of Trouble? Return Migration of EU Enlargement Migrants during the Crisis", Institute for the Study of Labor (IZA), available at:

https://pdfs.semanticscholar.org/374f/86f3e8e6aee36a84c318c991c1cea66497ab. pdf (accessed 27 February 2018).

Zikic, J. (2015), "Skilled migrants' career capital as a source of competitive advantage: implications for strategic HRM", The International Journal of Human Resource Management, Vol.26 No.10, pp.1360-1381. 